\title{
Van İli Merkez İlçede Küçükbaş Hayvancılık Faaliyetleri ve Genel Sorunlar: II. İşletmelerde Yetiştirme İşleri
}

\author{
Aşkın YILDIZ ${ }^{1}$, Turgut AYGÜN*2 \\ ${ }^{1}$ Van Yüzüncü Yıl Üniversitesi, Fen Bilimleri Enstitüsü, Zootekni Anabilim Dalı, 65080, Van, Türkiye \\ ${ }^{2}$ Van Yüzüncü Yıl Üniversitesi, Ziraat Fakültesi, Zootekni Bölümü, 65080, Van, Türkiye
}

Aşkın YILDIZ, ORCID No: 0000-0003-0939-8919, Turgut AYGÜN, ORCID No: 0000-0002-0694-6628

\begin{tabular}{|c|c|}
\hline MAKALE B İ L GISI & ÖZET \\
\hline Araştırma Makalesi & \multirow{10}{*}{ 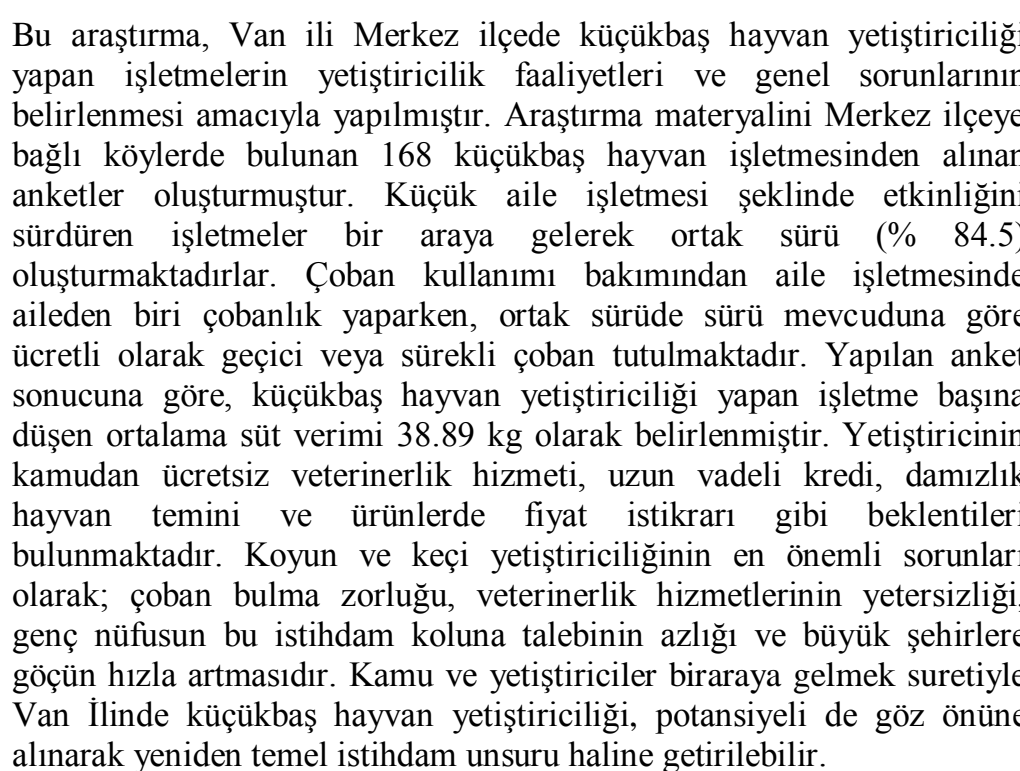 } \\
\hline $\begin{array}{l}\text { Bu makale, birinci yazarın tezli } \\
\text { yüksek lisans tezinin bir bölümünden } \\
\text { özetlenmiştir. }\end{array}$ & \\
\hline $\begin{array}{l}\text { Geliş: } 11.03 .2021 \\
\text { Kabul: } 05.05 .2021\end{array}$ & \\
\hline Anahtar Kelimeler & \\
\hline Aile i & \\
\hline & \\
\hline Koyunculuk & \\
\hline & \\
\hline Yetiştirme işleri & \\
\hline $\begin{array}{l}\text { * Sorumlu Yazar } \\
\text { turgutaygun@hotm }\end{array}$ & \\
\hline
\end{tabular}

\section{Activities of Small Ruminant Husbandry and General Problems in Van Central District: II. Breeding Practices in Enterprises}

\section{ARTICLE INFO}

\section{Research Article}

This article is summarized from part of the first author's master's thesis.

Received : 11.03 .2021

Accepted : 05.05.2021

\section{ABSTRACT}

This research was performed to determine the breeding activities of small ruminant husbandry enterprises and their general problems in central district of Van. Research material has been created 168 small ruminant firms in the villages of the central district of Van. Coming together in the form of small family-run business that operates form the common herd $(84.5 \%)$. In respect to using the shepherd, a member of family is selected as shepherd in family run while temporary or permanent shepherds are procured according to number of herd in common lot. According to survey result, average milk production per the farming of small ruminant is determined as $38.89 \mathrm{~kg}$. Cultivators have expectations such as free veterinary service, long-term credit, supply of breeding animals and products in the price stability from government. The most important issues of sheep and goat farming are the difficulty of finding shepherd, lack of veterinary services, lack of demand for field this operation of young people and the rapid increase of migration to big 
* Corresponding Author

turgutaygun@hotmail.com cities. By coming together with the public and the breeders, small ruminant breeding of Van Province can be transformed into a basic employment element again, taking into account its potential.

\section{Giriş}

Bir ülkenin gelişmişlik düzeyi ne olursa olsun gıda maddeleri üretimini garanti altına alması gerekmektedir. Gelecekte gıda maddelerinin temininde sorun yaşanmaması için bu alanda milli bir tarım politikasının oluşturulması ve bunun kalıcı olması zorunlu hale getirilmelidir. Hayvancılık için büyük bir potansiyele ve iklim yapısına sahip olan Türkiye'de üreticiler, yıllardan beri gelen alışkanlıkları gereği, kendi kendine yeterliliği benimseyen kapalı bir üretim sistemi modeli içerisinde, hayvansal ürün ihtiyacını karşılama çabasında olmuşlardır.

Küçükbaş hayvansal üretim, insanların dengeli beslenmesi için gerekli olan temel besin maddesi olan et, süt, gibi ürünleri sağlaması yanında deri, yapağı gibi ürünlerle giyim ve dokuma sanayine hammadde kaynağı sağlaması ile kullanılmayan işgücünü çalışır hale getirmesi bakımından da önemlidir. Küçükbaş hayvan yetiştiriciliği, iklim ve yapısı bakımından bitkisel üretime uygun olmayan, sığırlar tarafından değerlendirilemeyen zayıf mera ile nadas, anız ve diğer alanları değerlendirerek insan beslenmesine katkıda bulunan bir hayvancılık faaliyetidir. Küçükbaş hayvanlar yeme karşı kanaatkâr olduğundan çoğu kez yalnız mera ile yetinebilmektedirler. Özellikle de kuraklık, aşırı soğuk, ani iklim değişiklikleri ve bazı hastalıklara karşı dayanıklı hayvan olmaları nedeniyle gelişmemiş ve az gelişmiş ülkelerdeki küçük ve orta ölçekli işletmelerin en çok tercih ettiği hayvan türleridirler (Kaymakçı, 2006; Anonim, 2020a).

Günümüzde koyun-keçi dünyanın çeşitli yerlerinde birbirinden farklı çevre koşullarında çok geniş bir yaşama alanı bulmuş ve yetiştiriciye önemli gelir sağlamaktadır. Bunun önemli sebebi de bakım ve beslenmesi büyükbaş hayvanlara nazaran daha kolay olması çok farklı iklim ve çevre koşullarına ayak uydurmaları ve bitkisel üretimin yapılamadığı yağışı yetersiz, verimsiz geniş çayır mera ve nadasa bırakılan alanları çok iyi değerlendirebilme yetenekleridir. Dünya koyun varlığının büyük bir çoğunluğu Avrupa, Ön Asya, Yeni Zelanda, Avustralya, Orta Doğu ülkeleri ve Güney Amerika'da bulunmaktadır. Dünya keçi varlığının büyük çoğunluğunun ise özellikle gelişmişlik düzeyi geri kalmış ülkelerin bulunduğu Asya (\% 57.8) ve Afrika (\% 31.5) kıtalarında olduğu bildirilmektedir (Araç, 2007; Anonim, 2020b).

Türkiye'de tarım işletmeleri, hızlı nüfus artışına karşın işgücü talebini nüfus artışına uygun düzeyde karşılayamaması ve yeterli düzeyde tarımsal gelişmenin sağlanamaması nedeniyle küçük kapasiteli işletmelere düzeyindedir. Türkiye'de küçükbaş hayvan yetiştiriciliği bakım ve beslenme şartları yeterli olmayan küçük aile tipi işletmeciliği şeklinde yapılmaktadır. Mevcut koyun varlığının \% 97'sinden fazlasını Akkaraman, Morkaraman Dağlıç, Kıvırcık, İvesi, Karayaka ve diğer yerli ırklardan oluşmaktadır (Anonim, 2021).

Van ili Merkez ilçeye bağlı bazı köylerde gerçekleştirilen bu anket çalışmasının amaçları şunlardır:

-Küçük aile işletmeleri biçiminde şekillenen işletmelerde koyun-keçi yetiştiriciliğinin bu işletmelerdeki yerini belirlemek, 
-Başlıca koyun-keçi yetiştirici uygulamalarını tanımlamak,

-Küçükbaş hayvan yetiştirme etkinlikleri çerçevesinde oluşan işbirliği alışkanlıklarının kimi ayrıntılarını ve işletmelerde ekstansif yetiştirme koşullarının duyarlı bir tanımını ortaya koymak şeklinde sıralanabilir. Bu çalışmanın, bölge küçükbaş hayvancılığının tanımlanması bakımından bir kaynak özelliği taşıyacağı ve sorunların çözümüne yönelik alınacak önlemlerin oluşturulması konusunda yön verici olacağı düşünülmektedir.

\section{Materyal ve Yöntem}

\section{Materyal}

Van ili Merkez ilçeye bağlı Aşit, Bakraçlı, Beşçatak ve Gövelek köyleri; Erçek beldesi Merkez ve Ağzıkara, Arıtoprak, Aşağı Gölalan, Yukarı Gölalan, Çalımlı, Değirmenarkı, Ilıkkaynak, Karagündüz, Karakoç, Kaymaklı, Kozluca, Ortanca, Yatıksırt ve Yukarıüneyce köyleri; Timar beldesine bağlı Ağartı, Akçaören, Alaköy, Arısu, Atmaca, Bağdaşan, Çolpan, Değirmenözü, Dilimli, Ermişler, Gedikbulak, Güvençli, Halkalı, Kolsatan, Kumluca, Mollakasım, Ocaklı, Pirgarip, Tabanlı, Topaktaş, Yeniköşk ve Yeşilsu köyleri olmak üzere toplam 41 yerleşim yerinde şansa bağlı olarak seçilmiş toğlam 168 küçükbaş (koyun-keçi) hayvancılık işletmesi araştırmanın materyalini oluşturmuştur. İncelenen işletmelerin 74'ü Erçek beldesi köylerinden, 21'i Merkez ilçe köylerinden, 73'ü Timar beldesi merkezine bağl1 köylerden oluşmaktadır (Tablo 1).

Çalışmanın yürütüldüğü işletmeler için düzenlenen bir anket formu yoluyla işletme sahipleri ile yüz yüze görüşülerek, işletmelerin küçükbaş hayvancılık faaliyetleri, işletmelerde uygulanan yetiştirme uygulamaları ve genel sorunlarına ilişkin veriler toplanmıştır.

Tablo 1. İncelenen işletmelerin belirlenen merkezlere göre dağılımı

Table 1. Distribution of the enterprises examined according to the centers

\begin{tabular}{lcc}
\hline İşletmeler & İşletme Sayısı & İşletme Oranı (\%) \\
\hline Erçek & 74 & 44.0 \\
Merkez & 21 & 12.5 \\
Timar & 73 & 43.5 \\
Toplam & 168 & 100.0 \\
\hline
\end{tabular}

\section{Yöntem}

Araştırmanın materyali olan 168 işletmeden araştırmacılar tarafından anketle toplanan veriler, üzerinde durulan özelliklerden sürekli değişkenler için tanımlayıcı istatistikler; ortalama, standart hata, minimum ve maksimum değerler olarak ifade edilirken, kategorik değişkenler için sayı ve yüzde olarak ifade edilmiştir. Sürekli değişkenler bakımından eğitim durumu grupları arasında fark olup olmadığını belirlemek amacıyla tek yönlü varyans analizi (ANOVA) yapılmıştır. Kategorik değişkenler arasındaki ilişkiyi belirlemede Ki-kare testi yapılmıştır. Hesaplamalarda istatistik önemlilik düzeyi \% 5 olarak alınmış ve hesaplamalarda SPSS (2013) istatistik paket programı kullanılmıştır. 


\section{Bulgular ve Tartışma}

Van ili Merkez ilçede ve ilçeye bağlı bazı köylerde küçükbaş hayvan yetiştiriciliği yapan işletme sahipleriyle yapılan görüşmeler sonucunda, kimi yetiştirme uygulamaları ve genel sorunları gibi konulara ilişkin bilgiler alınmıştır.

\section{Yetiştirme İşleri}

\section{Koç-teke katımı}

Koç katım zamanı, süresi, şekli ve damızlık koç-teke teminine dair bulgular Tablo 2'de verilmiştir. Bu sonuçlara göre koyun-keçi işletmelerinde koç-teke katımı döneminde tamamen (\% 100) serbest aşım yöntemi uygulandığı belirlenmiştir. Bu koç katımı yönteminde yeterli sayıda koç/teke sürüde bulundurulmaktadır. Ancak, bu durumda hangi erkek hayvanın hangi dişi hayvan ile çiftleştiği tespit edilememektedir.

Koyun-keçi işletmelerinin \% 58.9'unda kendi koç-tekesini kullanma eğilimi vardır. Kendi koç-tekesi bulunmayan işletmelerin \% 33.9'u koç-tekeleri ortak sürüde kullanmaktadırlar. Dellal ve ark. (2002a) tarafindan Şanlıurfa, Gaziantep ve Adıyaman ilinde incelenen küçükbaş hayvancılık işletmelerinin sırasıyla \% 84.2, \% $95.9, \quad \% \quad 87.8$ ve \% 96.2'inde koç ve tekelerin yıl boyu sürü içerisinde tutuldukları saptanmıştır. Başka bir çalışmada (Koyuncu ve ark., 2005), yıl boyu serbest koç veya teke katımı yöntemi uygulandığını, koç ve tekelerin sürekli sürü içinde kaldıklarını belirledikleri bulgularla benzerlik tespit edilmiştir. Köyün ortak sürüsünden damızlık erkek hayvan elde etme durumu olmadığı durumlarda, kendi işletmesinde damızlık hayvanı bulunmayan işletmelerin \% 7.1'i damızlık koç-teke ihtiyacını başka köylerdeki işletmelerden karşılamaktadırlar. Sürülerde kullanılan koç-teke sayısı 0-10 baş arasında değişmektedir. Ankete katılan küçükbaş hayvan yetiştiricilerinin \% 92.9'u koç-teke katımından önce kızgınlığı toplulaştırma yapmadığ1 ve \% 7.1'i ise kızgınlığ 1 toplulaştırma yaptığını bildirmişlerdir (Tablo 2).

Küçükbaş hayvan işletmelerinin \% 81.5'i Eylül ayında, \% 15.5'i Ekim ayında, \% 2.4'ü Ağustos ayında ve \% 0.6'sının Temmuz ayında koç-teke katımı yaptıkları tespit edilmiştir. Koç katımı en yoğun Eylül-Ekim aylarında yapılmaktadır. Küçükbaş hayvan yetiştiricilerinin \% 27.4'ü koç-teke katım süresini 61-120 gün arasında yaptırdıkları, \% 23.8'i 241-300 gün arasında gerçekleştirdikleri belirlenmiştir (Tablo 2).

Koç-tekelerin sürüde kalma süreleri bakımından farklılık bulunmaktadır. Koçtekelerin sürüde kalma süreleri bakımından yetiştiricilerin fazla duyarlı olmadıkları gözlenmiştir. Koç-tekelerin sürüde kalma süreleri uzadıkça, kuzu-oğlak doğumları yıl içerisine dağılarak iş yükünü artırmaktadır. Koç ve tekelerin sürüye katım saati konusunda zaman sınırlaması olmadığı, işletmelerin \% 99.4'ü koç ve tekelerini aşım ayları boyunca sürüden hiç çıkarmadan sürekli bulundurdukları tespit edilmiştir. Kaymakçı ve ark.'nın (1998) koç katım zamanının Eylül-Ekim aylarında gerçekleştiği bulgusu ile bu araştırmadaki bulgular örtüşmektedir. Koyuncu ve ark.'nın (2006) bildirdiğine göre, teke katımı incelenen işletmelerde genellikle Temmuz- Ağustos aylarında başladığı ve Ekim-Kasım aylarında sona erdiği ifade edilmekte ve bu anketteki bulgulardan farklılık göstermektedir. Van İlinde koçteke katım zamanın daha geç başlama sebebinin iklimsel farklılığa dayandığ düşünülmektedir. 
Tablo 2. İşletmelerdeki koç-teke katımına ilişkin özellikler

Table 2. General features for the mating in farms

\begin{tabular}{|c|c|c|c|}
\hline & & $\mathrm{n}$ & $\%$ \\
\hline \multirow{3}{*}{$\begin{array}{l}\text { Koç- Teke katım } \\
\text { yöntemi }\end{array}$} & Elde aşım & 0 & 0 \\
\hline & Yapay tohumlama & 0 & 0 \\
\hline & Serbest & 168 & 100 \\
\hline \multirow{3}{*}{$\begin{array}{l}\text { Kendine ait koç-teke } \\
\text { kullanım durumu }\end{array}$} & Evet & 99 & 58.9 \\
\hline & Hayır & 12 & 7.1 \\
\hline & Koç-tekeyi ortak sürüden temin etmek & 57 & 33.9 \\
\hline \multirow{2}{*}{$\begin{array}{l}\text { Kızgınlığ } 1 \text { toplulaştırma } \\
\text { durumu }\end{array}$} & Evet & 12 & 7.1 \\
\hline & Hayır & 156 & 92.9 \\
\hline \multirow{4}{*}{ Koç-teke katım ayı } & Temmuz & 1 & 0.6 \\
\hline & Agustus & 4 & 2.4 \\
\hline & Eylül & 137 & 81.5 \\
\hline & Ekim & 26 & 15.5 \\
\hline \multirow{7}{*}{$\begin{array}{l}\text { Koç-teke katım süresi } \\
\text { (gün) }\end{array}$} & Sürekli & 27 & 16.1 \\
\hline & $1-60$ & 12 & 7.1 \\
\hline & $61-120$ & 46 & 27.4 \\
\hline & $121-180$ & 19 & 11.3 \\
\hline & $181-240$ & 20 & 11.9 \\
\hline & $241-300$ & 40 & 23.8 \\
\hline & 301 ve üzeri & 4 & 2.4 \\
\hline \multirow{4}{*}{ Koç-teke katım saati } & Sabah & 1 & 0.6 \\
\hline & Öğle & 0 & 0 \\
\hline & Akşam-gece & 0 & 0 \\
\hline & Sürekli & 167 & 99.4 \\
\hline
\end{tabular}

Küçükbaş hayvan yetiştiriciliğinde koç-teke katımı dönemi yemlemesi önem arz etmektedir. $\mathrm{Bu}$ dönemdeki yetersiz besleme döl verimini olumsuz etkilemektedir. Aşım mevsiminden yaklaşık üç-dört hafta önce ve aşımları takip eden üç-dört hafta devam eden sürede, koyunlar, keçiler ile koç ve tekeler arpa ve kaliteli kuru ot verilerek aşım dönemine hazırlamaktadırlar. Bu sebeple koç-teke katımı döneminde uygulanacak bir ek yemleme (flushing) ile koyunlarda yumurtlama sayısı \% 20 dolayında artırılabileceği, koç ve tekelerde devamlı aşım kondisyonunda bulunduğu, sperm sayısının arttığı ve embriyo kayıplarının en az düzeye indirilebileceği belirtilmektedir (Kaymakçı, 2006). Bu uygulamanın faydalarının üreticiler tarafından bilinmesine rağmen, uygulama aşamasında işletmeler tarafindan ek masraf gerektirdiği düşüncesiyle yetersiz kaldığı tespit edilmiştir. Küçükbaş hayvancılık işletmelerinin aşım mevsiminde koyun ve keçilere \% 35.7 oranında ek yem verdikleri ve \% 64.3'ünde ise ek yemleme yapmadıkları tespit edilmiştir. Bu bulgular Dellal ve ark.'nın (2002a) koyun ve keçilere ek yem verme (\% 67.3) oranına ve Tölü ve ark.'nın (2007) yetiştiricilerin \% 47'sinin aşım öncesinde ek yemleme yapmadıkları bulgusuna yakın bulunmuştur. Ayrıca Bilginturan (2008) tarafindan, koyunculuk işletmelerinin \% 74.7'sinin ve keçicilik işletmelerinin \% 92.5'inin ek yemleme yaptırmadıkları şeklinde elde edilen bulguları ile uyum göstermektedir. 


\section{Doğum}

Van ili ve çevresinde küçükbaş hayvan doğumlarında, \% 80.4 oranında güç doğum olsa bile pek müdahale yapılmamaktadır. Ağıllarda modern tarzda doğum bölmesi yoktur ve mevcut bölmelerde ilkel şartlarda oluşturulan tahtadan yapılan bölmelerdir (Tablo 3).

Tablo 3. İşletmelerdeki doğum zamanı ve güç doğum oranı

Table 3. Parturition time and dystocia ratio in enterprises

\begin{tabular}{llcc}
\hline & & $\mathrm{n}$ & $\%$ \\
\hline \multirow{2}{*}{ Güç doğum } & Evet & 135 & 80.4 \\
& Hayır & 33 & 19.6 \\
\hline \multirow{3}{*}{ Doğum ayı } & Aralık & 7 & 4.2 \\
dağılımı & Ocak & 5 & 3.0 \\
& Şubat & 84 & 50.0 \\
& Mart & 72 & 42.9 \\
\hline
\end{tabular}

Tablo 3'de de görüldüğü gibi, koyun- keçi doğumların \% 50'sinin Şubat ayında ve \% 42.9'un Mart ayında gerçekleştiği saptanmıştır. Genellikle bölgede doğum sezonu Şubat sonu Mart başına rastladığından iki ay değerlerinin birbirine yakın olduğu tespit edilmiştir. Az da olsa Aralık (\% 4.2) ve Ocak (\% 3) aylarında da doğumlar görülebilmektedir. Benzer bir sonuç da Tölü ve ark.'nın (2007) yaptığı çalışmada, doğumların Ekim-Mart ayları arasında ve en yoğun doğum oranının \% 60 olarak Aralık-Ocak-Şubat aylarında gerçekleştiği bulgusudur.

\section{Să̆ım ve süt verimi}

Küçükbaş hayvancılık işletmelerinde yapılan bu ankette işletmelerdeki sağım işlerinin büyük çoğunluğunun elle yapıldığı belirlenmiştir. İşletmeler arasında sağım sayısı bakımından farklılık gözlenmiştir (Tablo 4).

Çalışmada laktasyon süresi en fazla 3-4 ay, laktasyon süt verimi ortalaması $38.89 \mathrm{~kg}$, Sağımlar günde bir (öğlen) veya iki (sabah-akşam) kez yapıldığı gibi hiç sağım yapılmadan sütün tamamen yavruya bırakıldığı durumlar da söz konusudur. Günde 1 kez (öğlen) sağım yapan işletmelerin oranı \% 75.6 iken, günde 2 kez (sabah-akşam) sağım yapan işletmelerin oranı \% 22.6 ve hiç sağım yapmayanların oranı \% 1.8'dir. Bunun gerekçesi ise süt verimi yetersiz olan hayvanlardan elde edilen süt gelirlerinin, dışarıdan temin edilecek sağım ve işgücü masraflarını karşılayamayacak olmasıdır. İlk sağım işlemi doğumdan 1-3 ay sonra başlamaktadır. Bu ilk ayda süt tamamen yavruya bırakılmaktadır. İşletmelerde doğum sonrası ilk bir ay içinde hiç süt sağımı yapılmadığı, bir aydan sonra ise emiştirme ile sağımı beraber yaptıkları tespit edilmiştir. Sağıma başlama zamanı olarak elde edilen sonuçlar, Kaymakçı ve ark.'nın (1998) Doğu Anadolu da koyunların sağımına başlama zamanı olarak kuzulamadan 13 ay sonra başladığı sonucuna benzer bulunmuştur. 
Tablo 4. İşletmelerde sağım ve emiştirme işleri

Table 4. Milking and suckling practices in enterprises

\begin{tabular}{|c|c|c|c|}
\hline & & $\mathrm{n}$ & $\%$ \\
\hline \multirow{3}{*}{$\begin{array}{l}\text { Günlük emiştirme } \\
\text { durumu }\end{array}$} & 1 defa & 29 & 17.3 \\
\hline & 2 defa & 133 & 79.2 \\
\hline & $\begin{array}{l}\text { Kuzu oğlak sürekli anayla } \\
\text { birlikte }\end{array}$ & 6 & 3.6 \\
\hline \multirow{6}{*}{ Sütten kesim yaşı } & 2 aylik & 1 & 0.6 \\
\hline & 3 aylik & 27 & 15.1 \\
\hline & 4 aylik & 49 & 29.2 \\
\hline & 5 aylik & 70 & 41.7 \\
\hline & 6 aylik & 19 & 11.3 \\
\hline & 7 aylık & 2 & 1.2 \\
\hline \multirow{2}{*}{$\begin{array}{l}\text { Emiştirme süresince } \\
\text { sağım yapılma durumu }\end{array}$} & Evet & 153 & 91.1 \\
\hline & Hayır & 15 & 8.9 \\
\hline \multirow{8}{*}{ Sağım süresi (ay) } & Hiç sağmıyor & 3 & 1.8 \\
\hline & 1 ay & 3 & 1.8 \\
\hline & 2 ay & 37 & 22 \\
\hline & 3 ay & 70 & 41.7 \\
\hline & 4 ay & 37 & 22.0 \\
\hline & 5 ay & 15 & 8.9 \\
\hline & 6 ay & 1 & 0.6 \\
\hline & 7 ay & 2 & 1.2 \\
\hline \multirow{3}{*}{ Sağım sayısı } & Hiç sağılmıyor & 3 & 1.8 \\
\hline & 1 & 127 & 75.6 \\
\hline & 2 & 38 & 22.6 \\
\hline \multirow{3}{*}{ Süt sağım yöntemi } & Sağım yapmayanlar & 3 & 1.8 \\
\hline & Elle sağım & 165 & 98.2 \\
\hline & Makineli sağım & 0 & 0 \\
\hline
\end{tabular}

Benzer şekilde Aksoy ve Yavuz (2008), Doğu Anadolu bölgesinde yaptıkları çalışmada hayvancılık işletmelerinde, koyunculuk yapan yetiştiricilerin hepsinin hayvanlarını elle sağdıklarını bildirmektedirler. Küçükbaş hayvan yetiştiriciliğinde elle sağımdan ziyade makineli sağımın yerleştirilmesi, elde edilen sütün sağlıklı bir şekilde toplanması ve nitelikli ürünlere dönüştürülerek iç ve dış pazarlara sunulmasını sağlayacak düzenlemelerin yapılması gerekmektedir.

Sağım sayısı ister bir ister iki olsun, sağımla beraber emiştirme de yapılmaktadır. Günlük sağım sayısında meranın köye yakın olup olmama durumu da etkili olmaktadır. Sütten kesim sonrası sağım işlemine bir ay kadar devam edilmektedir. Özellikle Laktasyon süreleri bakımından işletmeler arasında farklılık olmakla beraber 1-7 ay arasında değişmektedir. İncelenen işletmelerde kuzu ve oğlakları sütten kesim yaşı \% 41.7 oranında 5 ay ve laktasyon süresi \% 41.7 oranında 3 ay olduğu tespit edilmiştir. Sağım süresini belirleyen sebeplerden biri işletmenin süt, yoğurt ve peynir ihtiyaçlarıdır. Sağım, sürü belirli saatlerde köye döndüğü zamanda ya da mera alanları içerisinde, özel olarak belirlenen alanlarda yapılmaktadır. Söz konusu alanda her sağımcı kendi koyununu sağmaktadır. Sağımın kadınlar tarafından gerçekleştirildiği gözlenmiştir. Anket yapılan işletmelerde günde bir kez emiştirme yapan 
işletmelerin oranı \% $17.3 \mathrm{iken}$, günde iki kez (sabah ve akşam) emiştirme yapanların oranı ise \% 79.2 olduğu belirlenmiștir. Bu değerler Dayan'ın (2007) Norduz koyunu yetiştiriciliği yapan işletmelerde, günde bir kez emiştirme yapan işletmelerin \% 12, günde iki kez emiştirme yapan işletmelerin \% 88 olduğunu bildirdikleri değerlerle örtüşmektedir.

Kuzu ve oğlakların sütten kesim yaşının 4-5 ay gibi geç sayılabilecek yaşlara kadar sürmesinin, kuzuların anayı uyarıcı etkisinden ötürü süt veriminin devamlılığını olumlu yönde etkilediği tespit edilmiştir. Buna karşın Tölü ve ark.'nın (2007) Biga çevresindeki koyun yetiştiricilerinin 60 günden önce kuzularını sütten kesmediklerini ve sütten kesim yaşı olarak 90 günlük yaşı tercih ettiklerini bildirmişlerdir. Koyuncu ve ark.'nın (2006) yaptıkları çalışmada Çanakkale keçi yetiştiricilerinin \% 60 oranında 45-60 günlük sütten kesim yaşını tercih ettikleri bildirilmektedir. Dellal ve ark. (2002a), Güneydoğu Anadolu Bölgesinin bazı illerinde kuzuların ortalama 3.2 ay, oğlakların ise 3.3 aylık yaşta sütten kesildikleri saptanmıştır. Elde edilmiş olan sütten kesim yaşına dair sonuç Tölü ve ark. (2007), Koyuncu ve ark. (2006) ve Dellal ve ark.'nın (2002a) yaptıkları çalışmalardan yüksek bulunmuştur. Dayan (2007), Norduz koyunu yetiştiriciliği yapan işletmelerde kuzuların sütten kesim yaşını ortalama 4 ay olarak saptadıkları değerleri, araştırma bulgularıyla örtüşmektedir.

Ekolojik koşulların süt hayvancılığına uygun olması, süt işletmelerinin süt üreticilerine yakın olması, Hatay'da yöresel süt ürünü çeşitliliği, Hatay halkının yerel süt ürünlerine yoğun talebi, talebin y1l boyunca devamlılığı sektörün güçlü yönlerini oluşturmaktadır. Eğitim düzeyinin düşük olması, süt ürünlerinin çabuk bozulabilen ürünler olması, örgütlenmenin yeterli olmayışı, ürünlerin ucuza alınmak istemesi, ürünlerde gerekli tanıtımın yapılamaması, işletmelerin düşük kapasite ile çalışması, bilgi sisteminin yeterli olmaması zayıf yönleri oluşturmaktadır (Küçük ve Tapkı, 2020).

Koyunculuk işletmelerinin \% 61.3'ünde ortalama günlük süt verimi miktarı 300-600 g, keçi işletmelerinin \% 51.2'sinde ortalama günlük süt verimi miktarı 600-1.000 g arasında bulunmuştur (Tablo 5). Elde edilen bu sonuçlar, Aksoy ve Yavuz'un (2008) küçükbaş hayvanların 3 ay sağılabildiği, koyunlarda günlük $0.2 \mathrm{~kg}$, keçilerde $0.3 \mathrm{~kg}$ ortalama günlük süt verimi miktarı bulgusundan yüksek bulunmuştur. Süt verimi bulgularının yetiştirici tahminlerine dayalı olması nedeni ile yörelere göre mutlak yaklaşımlar ortaya koymak mümkün değildir.

Tablo 5. İşletmelerde ortalama günlük süt verimi (g)

Table 5. Average daily milk yield in enterprises $(g)$

\begin{tabular}{llrrrr}
\hline & \multicolumn{4}{c}{ Koyunculuk işletmesi } & \multicolumn{2}{c}{ Keçicilik işletmesi } \\
\cline { 2 - 6 } & & $\mathrm{n}$ & $\%$ & $\mathrm{n}$ & $\%$ \\
Ortalama & 0 & 3 & 1.8 & 18 & 10.7 \\
günlük süt & $0-300$ & 44 & 26.2 & 4 & 2.4 \\
verimi (g) & $301-600$ & 103 & 61.3 & 42 & 25.0 \\
& $601-1.000$ & 16 & 9.5 & 86 & 51.2 \\
& 1.001 'den fazla & 1 & 0.6 & 18 & 10.7 \\
\hline
\end{tabular}

İşletme başına tespit edilen toplam süt verimi $38.89 \pm 1.46 \mathrm{~kg}$ bulgusu Ata'nın (2007)

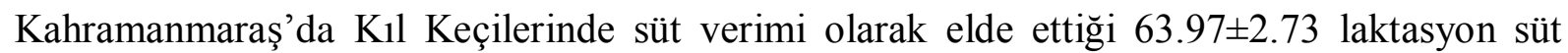
veriminden ve Atlıoğlu'nun (2007) Adana Tufanbeyli'deki koyunlardan elde ettiği ortalama 
süt verimi $(72.1 \pm 3.1)$ değerlerinden oldukça düşük bulunmuştur. Y1ldız ve Denk'in (2006) Akkaraman koyunlarından elde ettikleri laktasyon süt verimi $(39.73 \mathrm{~kg})$ değeri ile bu araştırma bulguları benzerlik göstermektedir. Yıldız ve Denk (2006), Van bölgesinde halk elinde yetiştirilen Akkaraman koyunlarında laktasyon süt verimini $39.73 \mathrm{~kg}$, günlük süt verimini $339 \mathrm{~g}$, laktasyon süresini 122.86 gün ve sütteki yă̆ oranını \% 6.62 olarak bildirmiştir. Van ili Gürpınar ilçesine ait Norduz bölgesinde yetiştiriciliği yapılan Norduz koyunlarının süt verimi ve süt bileşenlerinin incelendiği bir çalışmada, süt verimi yönünden 172 baş koyun incelenmiş, fakat süt bileşimi açısından 24 baş koyunun sütü kullanılmıştır. İncelenen koyunların laktasyon süt verimi $137.24 \pm 2.74$ ve laktasyon süresi ise $182.55 \pm 1.33$ gün olarak tespit edilmiştir (Ocak ve ark., 2009).

$\mathrm{Bu}$ araştırma sonucuna göre küçükbaş hayvanlardan elde edilen sütün büyük bir bölümünün, Van'ın yöresel dayanıklı otlu peyniri ve tereyağı yapılarak satışa sunulduğu belirlenmiştir. Van'da sütün mandıra ya da süt işleme tesisleri tarafından toplanması imkânı sınırlı olduğundan, üreticinin ürününün pazarlamasında sorun yaşamasına sebep olmaktadır. Özellikle koyun- keçi sütünün az olması ve işletmelerin dağınık olması nedeniyle, süt temini açısından büyükbaş hayvan işletmeleri tercih edilmektedir. Merkez köylerinde bulunan işletmelerde çiğ sütler, il merkezinde küçük market ve bakkallarda satışa sunularak pazarlanmaktadır.

\section{Kırkım}

Araştırmanın yürütüldüğü küçükbaş hayvancılık işletmelerinin tamamı koyunlarını kırkıp yapağılarını alırlarken, keçilerini kırkan işletmelerin sayısının az olduğu ve keçi kılından faydalanmanın olmadığı tespit edilmiştir (Tablo 6).

Tablo 6. İşletmelerde kırkım işleri

Table 6. Shearing practices in enterprises

\begin{tabular}{|c|c|c|c|c|c|c|c|c|c|}
\hline & & \multicolumn{2}{|c|}{ Koyun-Koç } & \multicolumn{2}{|c|}{$\overline{\text { Kuzu }}$} & \multicolumn{2}{|c|}{ Keçi- Teke } & \multicolumn{2}{|c|}{$\overline{\text { Oğlak }}$} \\
\hline & & $\mathrm{n}$ & $\%$ & $\mathrm{n}$ & $\%$ & $\mathrm{n}$ & $\%$ & $\mathrm{n}$ & $\%$ \\
\hline \multirow{5}{*}{ Kırkım ayı } & Mayıs & 4 & 2.4 & - & - & - & - & - & - \\
\hline & Haziran & 115 & 68.5 & 2 & 1.2 & 21 & 12.5 & - & - \\
\hline & Temmuz & 43 & 25.6 & 66 & 39.3 & 11 & 6.5 & - & - \\
\hline & A ğustos & 5 & 3.0 & 87 & 51.8 & 2 & 1.2 & - & - \\
\hline & Eylül & - & - & 11 & 6.5 & - & - & - & - \\
\hline \multirow{2}{*}{$\begin{array}{l}\text { Keçilerin } \\
\text { kilından } \\
\text { yararlanma } \\
\text { durumu }\end{array}$} & Evet & & & & & 3 & 1.8 & & \\
\hline & Hayır & & & & & 155 & 92.3 & & \\
\hline
\end{tabular}

Van ili merkez ilçeye bağlı köylerdeki küçükbaş hayvan yetiştiricilerinin kırkım işlerini Mayıs-Eylül ayları arasında yaptıkları görülmüştür. Mayıs ayı ortalarından itibaren sıcaklıkların artmasıyla birlikte yapağı ve kıl yağıltısı yumuşamaya başlar. Yağıltının yumuşama zamanı en uygun kırkım zamanı olduğunu gösterir. Ankete katılan işletmelerin \% 
68.5'i koyun ve koçları Haziran ayında, \% 51.8'i kuzuları daha sıcak ay olan Ağustos ayında kırkmaktadır. Keçi ve tekeler çoğunlukla kırkılmamakta veya kırkım gerektiği durumda ise \% 12.5 oranında Haziran ayında kırkılmaktadır. Oğlakların ise hiçbir işletmede kırkılmadığ1 tespit edilmiştir. İşletmelerin \% 100’ünde kırkımın, kırklıkla yapıldığ1 gözlenmiştir. Hiç bir işletmede kırkım makinesi olmadığı tespit edilmiştir. Dellal ve ark.'nın (2002a) yaptığı araştırmada, işletmelerin tamamı koyunlarını kırktığı, keçilerini kırkanların oranı ise \% 60.6 olduğu, koyunlar Nisan-Haziran, keçiler ise Mayıs-Temmuz aylarında kırkıldığ 1 ve kırkımın \% 99.6 oranında kırkım makasıyla yapıldığı bildirilmektedir.

\section{Banyo yapımı}

Van ili koyun ve keçi işletmelerinde tespit edilen banyo işlerine ilişkin sonuçlar Tablo 7'de verilmiştir.

Tablo 7. İşletmelerde banyo yaptırma durumu ve dönemi

Table 7. Bathing works and period in enterprises

\begin{tabular}{llcc}
\hline & & $\mathrm{n}$ & $\%$ \\
\hline \multirow{2}{*}{ Banyo yaptırma durumu } & Evet & 144 & 85.7 \\
& Hayır & 24 & 14.3 \\
\hline \multirow{3}{*}{ Kırkım öncesi veya sonrası banyo } & Banyo yaptırmayanlar & 24 & 14.3 \\
yaptırma durumu & Önce & 27 & 16.1 \\
& Sonra & 89 & 53.0 \\
& Hem önce hem sonra & 28 & 16.6 \\
\hline
\end{tabular}

Küçükbaş hayvancılık işletmelerinin \% 85.7'sinde hayvanlarına banyo yaptırdıkları görülürken, \% 14.3'ünde banyo yaptırmadıkları tespit edilmiştir. İşletmelerin \% 16.1'i kırkım yapmadan önce banyo yaptırdığını özellikle bu uygulamayı kuzular için yaptırdıklarını, koyun, koç ve keçileri de kırkımdan sonra banyo yaptırdıklarını bildirmişlerdir. Bu bulgular, Dellal ve ark'nın (2002a) GAP bölgesindeki işletmelerinin \% 54.6'sı koyun ve keçilere kırkımda banyo yaptırırlarken, \% 45.4'ünün yaptırmadığı sonucundan yüksek bulunmuştur. Bunun sebebi Van ilinin su kaynağ1 potansiyelinin (özellikle Van Gölü) Güney Doğu Anadolu bölgesinden yüksek oluşundan kaynaklandığı düşünülmektedir. Kırkımdan sonra banyo yaptıranların ve hem kırkım öncesi hem kırkım sonrası banyo yaptıranların oranı ise sırasıyla \% 53 ve \% 16.6'dır. Farklı merkez köyler arasında ve aynı köy içinde de farklı banyo yöntemlerinin görülmesine karşın, en yoğun olarak Van Gölü'nün sodalı suyundan yararlanıldığı belirlenmiştir. Bu banyo yöntemini, hayvanları ilaçlı suyla kovalar kullanılarak elle yıkama yöntemi izlerken, büyük enine kesilmiş variller içersinde yıkama şeklinde yapılan banyo yönteminin de uygulandığ 1 belirlenmiştir.

\section{Bazı verim özellikleri}

Van ili koyun ve keçi işletmelerinde tespit edilen bazı verim özelliklerine ilişkin sonuçlar Tablo 8'de verilmiştir.

Bulgular incelendiğinde, Van ilinde işletmelerde koyun ve koçlarda yapağı veriminin 1-3 kg arasında değiştiği ve ortalama $2.04 \mathrm{~kg}$ olduğu, keçi ve tekelerde kıl veriminin $0-1 \mathrm{~kg}$ 
arasında değiştiği ve ortalama verimin $0.37 \mathrm{~kg}$ olduğu, kuzularda yapağ 1 veriminin $0-2 \mathrm{~kg}$ arasında değiștiği, ortalama $1.21 \mathrm{~kg}$ olduğu görülmektedir. Bilginturan'in (2008) elde ettiğ $i$ Burdur ilindeki koyunculuk işletmelerinde ortalama yapağ işletmelerinde kıl verimi ortalama $0.22 \mathrm{~kg}$ sonuçları, elde edilen sonuçlara yakın bulunmuştur.

Tablo 8. İşletmelerdeki çeşitli verim özellikleri

Table 8. Some yield characteristics in enterprises

\begin{tabular}{llcccc}
\hline Özellikler & & $\mathrm{n}$ & En az & En çok & Ortalama \\
\hline $\begin{array}{l}\text { Yapağı/kıl } \\
\text { verimi } \\
(\mathrm{kg} / \mathrm{baş})\end{array}$ & $\begin{array}{l}\text { Koyun+Koçlarda Kırkım } \\
\text { miktarı }\end{array}$ & 167 & 1 & 3 & 2.04 \\
& Kuzu Kırkım miktarı(kg/baş) & 167 & 0 & 2 & 1.21 \\
& Keçi+Teke Kırkım miktarı(kg/br & 168 & 0 & 1 & 0.37 \\
\hline Döl verimi & Yavru atan koyun sayısı & 168 & 0 & 45 & $5.53 \pm 0.28$ \\
& 6. aya kadar ölen kuzu sayısı & 168 & 0 & 60 & $6.19 \pm 0.56$ \\
\hline Canlı & Koyunlarda canlı ağırlık & 167 & 20 & 70 & $40.51 \pm 0.74$ \\
ağırlık (kg) & Keçilerde canlı ağırlık & 152 & 0 & 60 & $31.82 \pm 0.71$ \\
\hline
\end{tabular}

Ankete katılan işletmelerde koyunlardaki canlı ağırlığın 20-70 kg arasında değiştiği ve ortalama $40.51 \pm 0.74 \mathrm{~kg}$ olduğu, keçilerde ergin canlı ağırlığın ortalama $31.82 \pm 0.71 \mathrm{~kg}$ olduğu tespit edilmiştir. Bulguların yetiştirici tahminlerine dayalı olması nedeniyle ortalamalara dayalı mutlak yaklaşımlar ortaya koymak imkân dâhilinde değildir. Elde edilen ikizlik oranı Atlığlu'nun (2007) Akkaraman Kangal koyunlarından elde ettiği \% 9.1 bulgusundan düşük bulunmuştur. Bilginturan (2008) koyunculuk işletmelerinde ikizlik oranını \% 27.36, keçicilik işletmelerinde ise \% 6.07 değeri elde edilen değerden yüksek bulunmuştur. Bilginturan (2008) kuzu ölüm oranını \% 7.57 ve oğlak ölüm oranını \% 10.73 olarak tespit etmişlerdir.

\section{İşletmelerde hayvan sağllğı ve koruma uygulamaları}

Ankette incelenen işletmelerde düzenli sağlık kontrollerinin işletmelerin büyük bir çoğunluğunda (\% 54.8) yapılmadığı belirlenmiştir. İşletmelerin sadece \% 45.2'si düzenli sağlık kontrolü yaptırmaktadır (Tablo 9).

Sağlık hizmeti alma konusunda yetiştiricilerde duyarlılık söz konusu değildir. Bunun sebebi hayvan sağlığı maliyetinin yüksek olduğudur. Araştırma kapsamında incelenen işletmelerin \% 79.8'inde, Bakanlığın uyguladığı aşılama programından faydalanıldığı ve diğer aşıları özellikle enterotoksemi ve çiçek aşılarının yetiştiriciler tarafından satın alınarak kendileri tarafından yapıldığı belirtilmiştir. 
Tablo 9. İşletmelerde hayvan sağlığı ve koruma uygulamaları

Table 9. Animal health and protection practices in enterprises

\begin{tabular}{llcc}
\hline & & $\mathrm{n}$ & $\%$ \\
\hline Düzenli veteriner & Evet & 76 & 45.2 \\
hekim kontrolü & Hayır & 92 & 54.8 \\
\hline \multirow{2}{*}{ Aş1 yaptırma durumu } & Evet & 134 & 79.8 \\
& Hayır & 34 & 20.2 \\
\hline Yaptırılan aşılar & Enterotoksemi & 86 & 48.8 \\
& Şap & 103 & 61.3 \\
& Çiçek & 116 & 69 \\
\hline \multirow{2}{*}{ Aş1 yaptırmama sebebi } & Aşı ücreti yüksek & 25 & 14.9 \\
& Gerekli görmüyor & 7 & 4.2 \\
& Hastalık çıkınca tedavi ettiriyor & 3 & 1.8 \\
\hline
\end{tabular}

Yapılan bu çalışmada Van küçükbaş hayvan işletmelerinde şap, çiçek ve enterotoksemi gibi koruyucu aşıların yaptırılmakta olduğu tespit edilmiştir. İşletmelerin en az bir çeşit koruyucu aşılama yaptırma oranı $\% 79.8$, hiç aşı yaptırmayanların oranı ise $\% 20.2$ olduğu tespit edilmiştir. Aşılardan şap aşısını yaptıranların oranı \% 61.3, çiçek aşısı yaptıranların oranı $\% 69$, enterotoksemi yaptıranların oranı $\% 48.8$ olarak tespit edilmiştir. Sağlık koruma konusunda Çanakkale'nin Biga ilçesinde de yetiştiricilerin yetersiz kaldığı ve belirli bir sağlık sorunuyla karşılaşmadan gerekli sağlık koruma tedbirleri almadıkları bildirilmiştir (Tölü ve ark., 2007). Çanakkale koyun yetiştiricilerinin sağlık koruma konusuna bakış açısı bu araştırmada elde edilen sonuçla örtüşmektedir. Küçükbaş hayvan yetiştiricilerinin aşı yaptırmama sebepleri olarak; aşı ücretini çok görenlerin oranı \% 14.9, aşılamayı gerekli görmeyenlerin oranı \% 4.2, hastalık çıktı̆̆ında ilaçla tedavi yöntemine başvuranların oranı \% 1.8 olduğu tespit edilmiştir. Benzer şekilde Koyuncu ve ark.'nın (2006) Çanakkale Koyun ve Keçi Yetiştiricileri Birliği üyesi keçicilik işletmelerinde yaptıkları çalışmada, işletmelerin \% 84.2'sinde yılda en az bir koruyucu aşı yapıldığı ifade edilmiştir. Başka bir çalışmada yetiştiricilerinin tamamına yakınının enterotoksemi hastalığına karşı aşı yaptırdığı, \% 50'sinin ise agalaksi ve şap aşılarını yaptırdığı, işletmelerin büyük bir bölümünün (\% 47), hayvanları hastalandığında ellerinde var olan ilaçları kullanarak tedavi ettikleri bildirilmektedir (Tölü ve ark. 2007). Aynı şekilde Bilginturan (2008) Burdur ilinde işletmelerin yılda en az bir çeşit koruyucu aşı yaptırdıklarını, koyunculuk işletmelerinde enterotoksemi, çiçek, şap, brucella aşılarından hepsini yaptıranların \% 64.9, keçicilik işletmelerinde aşıların hepsini yaptıranların \% 13.6, olduğunu tespit etmişler, koyunculuk işletmelerinin \% 85.1'inin ve keçicilik işletmelerinin \% 95'inin sürekli olarak bir veteriner hekimle çalışmadıkları, sadece aşılama ve hastalık çıkışı olduğunda veteriner hekime başvurduklarını belirtmişlerdir. Aynı şekilde Aksoy ve Yavuz (2008) araştırma kapsamındaki işletmelerin \% 77.5'inde şap, \% 37.9'unda brucella, \% 34.6'sında sarılık ve \% 16.5'i çiçek hastalığının görüldüğünü bildirilmektedir.

Türkiye'de hayvancıllğın tarımsal ekonomiye daha fazla katkıda bulunması, hayvancılı̆̆ın daha üst seviyelere ulaşması, hayvan başına alınan verimin istenilen seviyede olması ve hayvanlardan insanlara geçen salgın hastalıklardan toplum sağlığının korunması, ancak hayvan hastalıklarının kontrol altına alınması ile sağlanacaktır (Anonim, 2000). 
$\mathrm{Bu}$ araştırma sonuçlarına göre; yetiştiricilerin Bakanlığa bağlı ilgili birimin rutin aşılama programı dışında sorun yaşadıkları hastalıklara karşı maddi imkânları olduğu zamanlarda aşılama yaptırdıkları ve aşılama uygulamalarında süreklilik olmadığı görülmektedir. Özellikle son yıllarda kontrolsüz hayvan hareketleri nedeniyle, bulaşıcı hastalıklar ülkemizin dört bir yanına hızla yayılabilmektedir. Ayrıca kurban bayramı dönemlerindeki yoğun hareketlilik, sağlık sistemini tehdit etmekte ve bölge hayvancılığını olumsuz yönde etkilemektedir.

\section{Hayvan besleme ve yem temini}

İşletmelerde beslenme ve yem teminine ilişkin elde edilen sonuçlar Tablo 10'da verilmiştir.

Tablo 10'a göre Van ili merkez ilçeye bağlı köy işletmelerinin kaba yem olarak \% 71.4'ü saman, \% 60.74'ü yonca, \% 27.4'ü karışık ot (korunga+yonca), \% 11.9'u korunga, \% 30.4'ü çayırotu kullandıkları görülmektedir. İşletmelerin \% 50.6'sında süt verimini artırmak için herhangi bir ek yemleme yapılmadığı, \% 16.7'si süt yemi, \% 11.3'ü de arpa, \% 6.0'sında kepek kullanıldığı belirlenmiştir.

İncelenen işletmelerin \% 35.7'sinde gebe ve laktasyondaki hayvana özel besleme yapıldığı, \% 64.3'ünde ise özel besleme yapılmadığı gözlenmiştir. İşletmelerin \% 35.7'sinde flushing uygulamanın bilincinde olup aşım mevsiminde enerji oranı yüksek arpa ile yemleme yapılmakta, \% 64.3'ünde ise ek yemleme uygulaması yapılmamaktadır.

Araştırmada Van ili küçükbaş hayvan işletmelerinin \% 38.7'sinde sütten kesim sonras1 2-3 aylık dönemde meraya ek olarak saman, kes, arpa, kepek ve fabrika yeminden oluşan bir rasyonla besleme yapıldığı belirlenmiştir. Benzer bir sonuçta Tölü ve ark. (2007) tarafindan tespit edilmiştir. Balıkesir ilinde işletmelerin \% 44.5'inde sütten kesimi izleyen dönem içinde 2-3 süren ve fabrika yemi, buğday, arpadan oluşan bir rasyon ile besi yapılmaktadır.

Meraya ek olarak kaba yemlerden yonca kuru otu, korunga kuru otu, çayır kuru otu ve saman (buğday- arpa), kesif yem olarak ise arpa kırı̆̆ 1 , kepek veya besi yemi kullanılmaktadır. Elde edilen bu bulgular Dellal ve ark.'nın (2002b) GAP bölgesinde Mera ve yaylada otlatma dışındaki yem kaynakları sırasıyla tane yem, saman, anız, fabrika yemi ve silaj kullanıldığı bulgusu ile benzerlik göstermektedir.

\section{Mera ve yayla durumu ve mülkiyeti}

İncelenen küçükbaş hayvancılık işletmelerince yararlanılan meraların önemli bir bölümü \% 98.8'i köy orta malı meralardır. Kiralık mera kullanan işletme oranı da \% 1.2 olduğu bildirilmiştir. Van topraklarının \% 67'sini çayır mera alanları oluşturmaktadır. Bu oran bölge hayvancılığ 1 için önemlidir.

İncelenen küçükbaş hayvancılık işletmelerinin \% 81.5'inin meraya Nisan ayında çıktıkları, \% 18.5'inin Mayıs ayında; meraya çıktıları anlaşılmıştır. İşletmelerin büyük bir çoğunluğu (\% 75.6) hayvanlarını 7 ay süreyle merada tutmaktadır. Bununla birlikte, araştırmanın yürütüldüğü işletmelerin tamamının kış aylarında havaların iyi gitmesi durumunda da karın düştüğü ana kadar meralardan yararlanıldığı saptanmıştır. Van yöresinde koyun ve keçi yetiştiriciliği sistemi olarak yerleşik sistem olmakla birlikte ve az da olsa yayla hayvancılı̆g da yapılmaktadır. 
Tablo 10. İşletmelerde hayvan besleme ve yem temini

Table 10. Animal feeding and feed suply in enterprises

\begin{tabular}{|c|c|c|c|}
\hline & & $\mathrm{n}$ & $\%$ \\
\hline \multirow{5}{*}{ Kaba yem çeşitleri } & Saman & 120 & 71.4 \\
\hline & Yonca & 102 & 60.7 \\
\hline & Karış1k ot (korunga+yonca) & 46 & 27.4 \\
\hline & Korunga & 20 & 11.9 \\
\hline & Çayır otu & 51 & 30.4 \\
\hline \multirow{2}{*}{$\begin{array}{l}\text { Gebelik ve laktasyon } \\
\text { dönemi özel besleme }\end{array}$} & Evet & 60 & 35.7 \\
\hline & Hayır & 108 & 64.3 \\
\hline \multirow{4}{*}{ Kesif yem temini } & Yem bayii & 68 & 40.5 \\
\hline & Tarım kredi kooperatifi & 0 & 0 \\
\hline & Kesif yem kullanımı yok & 98 & 58.3 \\
\hline & Fabrikadan & 0 & 0 \\
\hline \multirow{9}{*}{$\begin{array}{l}\text { Süt artırımı için } \\
\text { verilen yem }\end{array}$} & $\begin{array}{l}\text { Süt artırımı için yemleme } \\
\text { yapmayanlar }\end{array}$ & 85 & 50.6 \\
\hline & Süt yemi & 28 & 16.7 \\
\hline & Süt yemi- kepek & 4 & 2.4 \\
\hline & Süt yemi- kepek -arpa & 3 & 1.8 \\
\hline & Süt yemi- arpa & 12 & 7.1 \\
\hline & Kepek & 10 & 6.0 \\
\hline & Kepek-arpa & 5 & 3.0 \\
\hline & Arpa & 19 & 11.3 \\
\hline & Şeker pancarı küspesi & 2 & 1.2 \\
\hline \multirow[t]{2}{*}{ Flushing uygulama } & Evet & 60 & 35.7 \\
\hline & Hayır & 108 & 64.3 \\
\hline \multirow{4}{*}{$\begin{array}{l}\text { Günlük yemleme } \\
\text { sayısı }\end{array}$} & 2 öğün & 56 & 33.3 \\
\hline & 3 öğün & 96 & 57.1 \\
\hline & 4 öğün & 14 & 8.3 \\
\hline & 5 öğün & 2 & 1.2 \\
\hline
\end{tabular}

Küçükbaş hayvanların meraya çıkarılma zamanı iklimsel faktörlere bağlı olarak Nisan ayı sonunda ve Mayıs ayı başlangıcında yapılmaktadır. Terzioğlu ve Yalvaç (2004) Van İlinde iki ayrı bölgede yaptıkları çalışmada, otlatmaya başlama zamanı olarak 10 Mayıs tarihini tespit ettiklerini bildirmektedirler. Anket yapılan işletmelerin \% 50'si meralarının yeterli olduğunu, hayvanların iyi beslendiğini, \% 26.2'si ise meraları orta dereceli bulurken, \% 23.2'si yetersiz bulduklarını belirtmişlerdir. 2000 yılından bu yana Bakanlık tarafından bitkisel ürünlere verilen destekten dolayı mera arazileri sürüm yapılarak tahrip edilmiş ve tarla haline getirilmiştir.

Koyuncu ve ark.'nın (2005) çalışmalarında Bursa, Balıkesir, Bilecik ve Çanakkale ilinde köy ortak merasından faydalanıldığını, çok az sayıda yetiştiricinin kiralık mera ve mülk meradan yararlandığg bulguları ile araştırma bulguları benzerlik göstermektedir.

\section{Besicilik faaliyetleri}

İncelenen işletmelerin \% 61.3'ü (103 işletme) besi faaliyeti yapmazken, sadece \% 
38.7'sinin (65 işletme) besi faaliyeti yaptığını ifade etmişlerdir. Besicilik yapan işletmelerin oranı Erçek Bucağı'na bağlı köylerde \% 26.2, Merkez köylerde \% 6.0 ve Timar Bucağı köylerinde \% 29.2 olarak bulunmuştur (Tablo 11).

Ele alınan işletmelerin besicilik yapanların tamamına yakınında toklu besisi ile ilgili özel bir besleme programı izlenmediği belirlenmiştir. Besi hayvanı olarak sütten kesim sonrasında damızlık fazlası erkek kuzuların tercih edildiği bildirilmiştir. İncelenen işletmelerin bazıları besi hayvanı alırken, \% 10.1'nin 4 aylık, \% 17.3'ünün 6 aylık, \% 8.9'unun 8 aylık, \% 1.8'inin ise 12 aylık yaş grubundaki hayvanları tercih ettikleri belirlenmiştir.

Tablo 11. İşletmelerde besicilik faaliyetleri

Table 11. Fattening activities in enterprises

\begin{tabular}{|c|c|c|c|}
\hline & & $\mathrm{n}$ & $\%$ \\
\hline \multirow{2}{*}{$\begin{array}{l}\text { Toklu besisinde } \\
\text { kaba yemi verme } \\
\text { durumu }\end{array}$} & Besi yapmayanlar & 103 & 61.3 \\
\hline & Serbest & 65 & 38.7 \\
\hline \multirow{5}{*}{$\begin{array}{l}\text { Toklu besisinde } \\
\text { yoğun yemi verme } \\
\text { durumu }\end{array}$} & Besi yapmayanlar & 103 & 61.3 \\
\hline & Serbest & 51 & 30.4 \\
\hline & Canlı ağırlığa göre & 6 & 3.6 \\
\hline & $500 \mathrm{~g} / \mathrm{baş}$ & 3 & 1.8 \\
\hline & $1 \mathrm{~kg} / \mathrm{baş}$ & 3 & 1.8 \\
\hline \multirow{5}{*}{$\begin{array}{l}\text { Besiye başlanılan } \\
\text { yaş grubu }\end{array}$} & Besi yapmayanlar & 103 & 61.3 \\
\hline & 4 ay & 17 & 10.1 \\
\hline & 6 ay & 29 & 17.3 \\
\hline & 8 ay & 15 & 8.9 \\
\hline & 12 ay & 3 & 1.8 \\
\hline \multirow{5}{*}{ Besi süresi } & Besi yapmayanlar & 103 & 61.3 \\
\hline & 2 ay & 9 & 5.4 \\
\hline & 3 ay & 37 & 22.0 \\
\hline & 4 ay & 10 & 6.0 \\
\hline & 5 ay & 9 & 5.4 \\
\hline \multirow{5}{*}{$\begin{array}{l}\text { Besi sonu canlı } \\
\text { ağırlık }\end{array}$} & Besi yapmayanlar & 103 & 61.3 \\
\hline & $25 \mathrm{~kg}$ & 10 & 6.0 \\
\hline & $30 \mathrm{~kg}$ & 2 & 1.2 \\
\hline & $35 \mathrm{~kg}$ & 7 & 4.2 \\
\hline & $40 \mathrm{~kg}$ ve üzeri & 46 & 27.4 \\
\hline \multirow{3}{*}{$\begin{array}{l}\text { Besi süresince } \\
\text { temiz su durumu }\end{array}$} & Besi yapmayanlar & 103 & 61.3 \\
\hline & Evet & 62 & 36.9 \\
\hline & Hayır & 3 & 1.8 \\
\hline \multirow{5}{*}{$\begin{array}{l}\text { Satışa sunma } \\
\text { durumu }\end{array}$} & Besi yapmayanlar & 103 & 61.3 \\
\hline & Van hayvan pazarında & 39 & 23.2 \\
\hline & Özel şirketlere & 4 & 2.4 \\
\hline & Diğer illere götürerek & 1 & 0.6 \\
\hline & Diğeri & 21 & 12.5 \\
\hline
\end{tabular}

Yetiştiricilerin \% 6'sı besiye aldıkları kuzuları $25 \mathrm{~kg}$ olduğunda, \% 1.2'si $30 \mathrm{~kg}$, \% 4.2 'si $35 \mathrm{~kg}, \% 27.4$ 'ünün ise $40 \mathrm{~kg}$ ve üzeri ağırlığa ulaştığında satışa sunduklarını 
bildirmişlerdir. Meraya ek olarak saman ya da kese; arpa, kepek ya da fabrika yemi karıştırılarak bir besleme uygulandığ1 tespit edilmiştir. Anketin yürütüldüğü işletmelerde sütten kesimi izleyen 2-3 aylik dönem de fabrika yemi, arpa ve kesten oluşan bir rasyon ile besi yapıldığı bildirilmektedir. Özellikle kurban bayramına rastlayan besi döneminde işletmelerin hayvanları özel şirketler tarafından toplandığı da belirlenmiştir.

Hayvan beslemede önemli bir yeri olan kesif yemin fiyatının yüksek olması ve yetiştiricinin beslenme konusundaki eğitim yetersizliği nedeniyle yeterli düzeyde kullanılmamaktadır. Beside günlük canlı ağırlık artışı göz önünde bulundurulmadan kaba ve kesif yem sürüye serbest bir şekilde sunulmaktadır. $\mathrm{Bu}$ durum besi hayvanlarının ihtiyaç duyduğu besin maddelerini yeterli miktarda alamamalarına ve yeterli canlı ağırlık artışı sağlayamamalarına sebep olduğundan karlı bir besicilik yapılamamaktadır. Küçükbaş yetiştiriciliğinde elde edilen gelirin çoğu canlı hayvan satışından sağlanmaktadır. Besi süresi sonunda hayvanlar $25 \mathrm{~kg}$ ile $40 \mathrm{~kg}$ arasında bir canlı ağırlığa sahip olunca pazara sunulmaktadir.

\section{Sonuç ve Öneriler}

Sonuç olarak, Van ili koyun ve keçi yetiştiriciliğinin genel yetiştirici uygulamaları ile sorunlarının belirlenmesi ve bölge küçükbaş hayvan üretim biçimlerinin tanımlanması amacıyla yapılan bu araştırmada, bölgede küçükbaş hayvancılığın ekstansif koşullarda, küçük aile işletmelerinde geleneksel bir yapıya bağlı olarak hem gelir getirici bir faaliyet hem de aile ihtiyaçlarına yönelik olarak yapıldığı tespit edilmiştir. Bölge yetiştiricilerinin temel hayvan yetiştirme konularında eğitilmesi ve işletme koşullarının iyileştirilmesi ile elde edilecek verimlerin artırılabileceği düşünülmektedir. Kamu, damızlık birlikleri ve yetiştirici biraraya gelmek suretiyle Van İlinde koyun-keçi yetiştiriciliğini, potansiyeli de göz önüne alınarak yeniden temel istihdam unsuru haline getirilebilirler.

\section{Kaynaklar}

Aksoy, A., Yavuz, F., 2008. Hayvancılık işletmelerinin Avrupa Birliğine uyumu ve rekabet edebilirliği; Doğu Anadolu örneği. Tarım Ekonomisi Dergisi. 14(1): 37-45.

Anonim, 2000. Doğu Anadolu Projesi Ana Planı. Mevcut Durum ve Analizi Raporu. DPT. Ankara.

Anonim, 2020a. Türkiye istatistik y1llı̆̆1 http://www.tuik.gov.tr. Türkiye İstatistik Kurumu, Ankara. Erişim tarihi: 04.07.2020.

Anonim, 2020b. FAO. Data Statistics. www.fao.org/datastatistics. Erişim tarihi: 04.12.2020.

Anonim, 2021. Sekizinci beş yıllık kalkınma planı. Hayvancılık Özel İhtisas Komisyonu Raporu. DPT: 2574-ÖİK: 587. https://www.sbb.gov.tr/ozel-ihtisas-komisyonuraporlari. Erişim tarihi: 13.01.2021.

Araç, B., 2007. Diyarbakır ili keçicilik işletmelerinin yapısal özellikleri. (Yüksek Lisans Tezi, basılmamış). Van Yüzüncü Y1l Üniversitesi, Fen Bilimleri Enstitüsü, Van.

Ata, M., 2007. Kahramanmaraş’tan Kıl keçilerinin süt verim özellikleri (Yüksek Lisans Tezi, basılmamış) Kahramanmaraş Sütçü İmam Üniversitesi, Fen Bilimleri Enstitüsü, Kahramanmaraş. 
Atlıŏlu, A., 2007. Adana İli Tufanbeyli İlçesi köylerinde koyun yetiştiriciliğinin karakterizasyon (Yüksek Lisans Tezi, basılmamış) Çukurova Üniversitesi, Fen Bilimleri Enstitüsü, Adana.

Bilginturan, S., 2008. Burdur ili Damılık Koyun ve Keçi Yetiştiriciler Birliği üyesi işletmelerin yapısal özellikleri ve sorunları üzerine bir araştırma. (Yüksek Lisans Tezi, basılmamış) Süleyman Demirel Üniversitesi, Fen Bilimleri Enstitüsü, Isparta.

Dayan, Y.A., 2007. Norduz koyunu yetiştiriciliği yapılan kimi işletmelerin yapısal özellikleri (Yüksek Lisans Tezi, basılmamış). Van Yüzüncü Yıl Üniversitesi, Fen Bilimleri Enstitüsü, Van.

Dellal, G., Eliçin, A., Tekel, N., Dellal, İ., 2002a. GAP Bölgesinde küçükbaş hayvan yetiştiriciliğin yapısal özellikleri. . Tarımsal Ekonomi Araştırma Enstitüsü, Proje Raporu 2002-1, Yayın No, 82, TKB, Ankara.

Dellal, İ., Keskin, G., Dellal, G., 2002b . GAP Bölgesinde küçükbaş hayvan yetiştiren işletmelerin ekonomik analizi ve hayvansal ürünlerin pazara arzı. Tarımsal Ekonomi Araştırma Enstitüsü, Proje Raporu 2002-2, Yayın No, 83, TKB, Ankara.

Kaymakçı, M., Karaca, O., Sönmez, R., 1998. Doğu Anadolu Bölgesi koyunculuğuna verilecek yön. Doğu Anadolu Tarım Kongresi Bildirileri, Erzurum, 14-18 Eylül 1998, s. 707-716.

Kaymakçı, M., 2006. İleri Koyun Yetiştiriciliği. Genişletilmiş 1. Baskı. Ege üniversitesi Basımevi, Bornova, İzmir, 365s.

Koyuncu, M., Uzun, Ş.K., Tuncel, E., 2005. Güney Marmara Bölgesi keçicilik işletmelerinin genel durumu ve verim özelliklerinin belirlenmesi üzerine araştırmalar I. Keçicilik işletmelerinin genel durumu. Ankara Üniversitesi Ziraat Fakültesi Tarım Bilimleri Dergisi. 11(4): 374-378.

Koyuncu, E., Pala. A., Savaş. T., Konyalı. A., Ataşoğlu. C., Daş. G., Ersoy. İ. E., Uğur. F., Yurtman. İ.Y., Yurt. H. H., 2006. Çanakkale Koyun ve Keçi Yetiştiricileri Birliği üyesi keçicilik işletmelerinde teknik sorunların belirlenmesi üzerine bir araştırma. Hayvansal Üretim Dergisi. 47(1): 21-27.

Küçük, R., Tapk1, N., 2020. Hatay ilinde süt ve süt ürünleri üreten işletmelerin GZFT analizi ile değerlendirilmesi, Journal of Animal Science and Products (JASP) 3(2): 134-142.

Ocak, E., Bingöl, M., Gökdal, Ö. 2009. Van yöresinde yetiştirilen Norduz koyunlarının süt bileşimi ve süt verim özellikleri. Yüzüncü Yıl Üniversitesi Tarım Bilimleri Dergisi. 19(2): 85-89.

SPSS, 2013. IBM SPSS Statistics 22.0 for Windows. Armonk, NY.

Terzioğlu, Ö., Yalvaç, N., 2004. Van Yöresi doğal meralarında otlatmaya başlama zamanı, kuru ot verimi ve botanik kompozisyonun belirlenmesi üzerine bir araştırma. Yüzüncü Y1 Üniversitesi Ziraat Fakültesi Tarım Bilimleri Dergisi. 14(1): 23-26.

Tölü, C., Daş, G., Yurdabak, S., Uğur, F., Konyalı, A., Savaş, T., Aktürk, D., Turkan, H., 2007. Türkiye'nin önemli hayvancılık bölgelerinden Biga koyunculuğuna genel bir bakış. V. Zootekni Bilim Kongresi Bildirileri, Van, 5-8 Eylül 2007, s: 1-9.

Yıldız, N., Denk, H., 2006. Van Bölgesin halk elinde yetiştirilen Akkaraman koyunlarda çeşitli verim özellikleri I. Döl ve süt verimleri. Fırat Üniversitesi Sağlık Bilimleri Dergisi. 20(1): 21-27. 